\title{
Directive Speech Acts of The Officer To Passengers On The Sea Transportation
}

\author{
Nuz Chairul Mugrib ${ }^{1}$, Sumarlam², Dwi Purnanto 3 \\ 1,2,3 Universitas Sebelas Maret, Indonesia \\ $\left\{{ }^{1}\right.$ nuzchairulmugrib@gmail.com $\}$
}

\begin{abstract}
. his study aims to describe directive speech acts on sea transportation. The directive speech act is focused on directive speech delivered by ship officers to passengers. This study used a qualitative research method. The techniques of collecting data are observation and recording. The data resources are spoken data from utterance of ship officers to passengers. Technique of analysis data uses means-end and contextual approach. The results of this study show that 76 data of directive speech acts on sea transportation include: asking, requesting, inviting, ordering, directing, requiring, expecting, prohibiting limiting, allowing, suggesting, advising and obliging.
\end{abstract}

Keywords: speech act, directive speech act, sea transportation

\section{INTRODUCTION}

Language in everyday life of human has important position. With language, humans can communicate and interact with their surroundings. Sumarlam et al. [1] explained that language has a main function as a communication device to convey the intent and information of speakers to hearers. As a device for communication, language is also very closely related to the context in which the language is delivered because the presence of context determines the intent and information of the language. In terms of linguistics, pragmatics is a study that focuses on understanding the meaning in the use of context-based language. Pragmatics is a study of language and context that is basic to account of language [2]. Context is a basic part and it is important to understand a language that is conveyed because without the context of the purpose of language, it will be difficult to understand. Thus, context is something that becomes an explanatory instrument for meaning sense [3].

In the Pragmatic study, there are a number of topics that are at the core of the discussion. Yan Huang explained that speech is one of the central topics of inquiry pragmatics [4]. Speech act is the ability of a person to use language to convey the messages or goals of speakers to hearers [5]. There are a number of speech acts that can be used to convey the intent of a language. Searle grouped speech acts into five types and one of them is directives. Directives are those kinds of speech act that represent attempts by the speaker to get the addressee to do something [4 p.20].

The usage of directive speech in communication is closely related to the response given by hearers to the speakers. The hearers can understand the intent conveyed by taking action in accordance with the speech delivered. In this case, a speaker must be able to use language that communicatively can show that the speaker has a desire which the hearer understands and can make it happen. In other words, the indicator that the speech is considered as directive speech act is marked by the existence of an action that must be carried out by the hearers after hearing the speech [1 p.52] 
The form of language specifically directive speech acts can be found in various aspects of the public life, including the language used as a means of communication on transportation. Transportation is a vehicle used by the community to travel or move. Transportation in general can be interpreted as an attempt to move, or move people or goods from a location, called the original location, to another location, which is usually called the destination location, for certain uses using certain tools as well [6]. Transportation has become part of the needs of the world community to help activities like the Indonesian people.

There are many types of transportation that are often used by the community to help them according to the conditions of their area. One type of transportation is sea transportation. Sea transportation is transportation that uses ships as a means of transportation to help move activities from one port to another. For the people of Indonesia as country which has many islands, sea transportation has an important role in helping the mobility of people from one place to another so that until now, the use of sea transportation is still often used.

On sea transportation, the usage of language is required in establishing good environmental conditions on the ship because language as a communication device is used to express intentions and information that can provide safety and comfort for people as users of sea transportation. The form of language communication or speech act that occurs on ships tends to use directive speech act that is there is the expectation expected by ship officers to ship passengers to be able to do or follow the purpose of the speech conveyed. Directive speech act that occurs can be through direct meetings with passengers or using a microphone that is on the ship. In carrying out this communication, the type of directive speech act used by the ship's officers also varies according to the context of the speech act intended.

Regarding the use of directive speech act on the sea transportation, there are a number of previous studies that have examined the concept of directive speech acts. The research conducted by Sumiatun [7] entitled "Teacher and Student Directive Speech Acts in Learning in Third Grade Tipo Palu SDN", Safar [8] entitled "Directive Speech Acts in The Transactions Sale at The Central Market of Watampone", and Qomariyah [9] entitled "Directive speech (TTD) of Teachers in Learning Arabic". The three studies have the same focus of discussion which is describing the form, the function of the directive speech act that occurs. Sumiatun [7] study aims to explain directive speech act that occurs between teachers and students in the learning process. The directive speech act used by the teacher to students includes: Command, Statement, Question, Request and Prohibit. The directive statement is delivered using direct and indirect sentences. Then, Safar's research [8] describes the use of directive utterances carried out between traders and buyers in the Central Market of Watampone. The directive speech acts used include asking, ordering, ordering, advising, and recommending. Furthermore, research conducted by Qomariyah [9] shows the directive speech acts used by teachers in Arabic learning include requesting, questions, requirements, prohibitives, permissives, and advisories. The speech was delivered in different sentence moods.

Based on the description above, the objectives to be achieved from this study are to explain the type of directive speech act used by ship officers when conveying information to passengers on the ship.

\section{METHODOLOGY}


This study focuses on directive speech acts that occur on the sea transportation. This study uses descriptive qualitative research using purposive sampling because the usage of purposive sampling is applied to achieve the objectives of the study [10]. In conducting this research, the location was on a ship Dorolonda (PELNI Ship) which carried passengers from Jakarta, Surabaya, and Makassar until Baubau on 15-18 February 2019. Regarding the focus of research on speech acts, data and sources of data from this study are speeches only delivered by ship officers to passengers on the ship Dorolonda. The data source is language in the form of speech delivered by the ship officers who are on the ship. Meanwhile, Data is about question in research. Sudaryanto said that data is understood as a special lingual phenomenon that contains and is directly related to the problem in question [11]. In addition, Santosa explained that data is the object of research, the reality that we make the focus of research, including places, participants, and events that surround that focus [10]. Therefore, the data in this study are utterances containing directive speech acts delivered by ship officers to passengers.

In the process of collecting data, the technique used is the technique of referring and recording. The study observed information conveyed by ship officers who were delivered directly through loudspeakers on ships, using microphone, and also face to face when ship officers met directly with passengers on ship. In addition, in the process of observing, the researcher also records each of the information to be listened again and it can be recorded as an initial step in data analysis later. Meanwhile, in the data analysis stage, this study uses the meanends and contextual pragmatic approach. The mean-ends are that researchers only focus on speech delivered by speakers [12]. In this case, the speaker is a ship officer who delivers a speech containing a directive speech act. Contextual analysts are the methods of analysis applied to data by basing, calculating, linking identity, existing contexts [13]. Directive speech acts always begin with the presentation of context.

\section{FINDINGS AND DISCUSSIONS}

Directive speech acts are a form of speech acts intended by speakers to make an influence so that the hearers want to do something. On the sea transportation, to establish conditions that are safety and comfort on the ship, language communication is often applied by ship officers to passengers on ships using directive speech act. When the officer communicates information to the passenger, the officer uses directive speech act which the ship officer expects an action taken by the passenger of the ship from the delivered speech. There are 13 types of speech that are categorized into directive speech acts that are used by officers to passengers, namely asking, requesting, inviting, ordering, directing, requiring, expecting, prohibiting, limiting, allowing, suggesting, advising and obliging. The following is a table of directive speech act data found on sea transportation.

\begin{tabular}{l|c|c|c}
\hline No & $\begin{array}{c}\text { Types of Directive } \\
\text { Speech acts }\end{array}$ & Frequency & Presentase \\
\hline 1 & Asking & 14 & 18,42 \\
\hline 2 & Requesting & 6 & 7,89 \\
\hline 3 & Inviting & 6 & 7,89 \\
\hline 4 & Ordering & 14 & 18,42 \\
\hline 5 & Directing & 10 & 13,16 \\
\hline 6 & Requiring & 4 & 5,26 \\
\hline
\end{tabular}




\begin{tabular}{l|c|c|c}
\hline 7 & Expecting & 2 & 2,63 \\
\hline 8 & Prohibiting & 5 & 6,58 \\
\hline 9 & Limiting & 2 & 2,63 \\
\hline 10 & Allowing & 3 & 3,95 \\
\hline 11 & Suggesting & 4 & 5,26 \\
\hline 12 & Advising & 3 & 3,95 \\
\hline 13 & Obliging & 3 & 3,95 \\
\hline & TOTAL & 76 & $100 \%$ \\
\hline
\end{tabular}

Based on the table above, data of the directive speech act obtained from the ship's officers' speech to passengers on Ship Dorolonda is 76 data. The speech data is divided into 13 types of sub directive speech acts with different frequency of usage by the ship's officer such as directive speech acts of asking and ordering are the most dominant compared to the other sub-speech acts used officers to passengers who are above the ship. The frequency of the use of directive speech act is also determined from the context that causes the speech act to occur on the ship. The following is data that show the usage of speech directives by ship officers to passengers.

\section{Asking}

\section{Data 1}

Speech Context:

This information was conveyed by the ship officer to all passengers who were on ship, approximately after one-hour Ship Dorolonda sailed from the port of Tanjung Priuk Jakarta to the Tanjung Perak Surabaya.

Speech Form:

Good Afternoon, Passengers. It was informed in about 15 minutes again; we will hold a ticket check and over baggage. To smooth ticket checking, passengers are asked respectfully to return to their respective places and prepare your ticket.

Data (1) is a form of speech containing a directive speech act asking. This can be seen in the lingual marker used in the speech, namely "asked respectfully". In general, the data (1) is the information about the speech which is delivered by the ship's officer before checking the ticket. The ticket inspection process will be carried out after the ship has left the port and before the ship arrives at the next port. The ship's officer will notify passengers on the ship via loudspeakers or microphone to ask all passengers to prepare their tickets. This is done by officers to provide ease and fluency for ship officers when ship officers go around on each deck of the ship and check every passenger ticket on ship.

\section{Requesting}

Data 2:

Context:

The information was conveyed by the ship's officer when the ship was still anchoring on the port of Tanjung Perak Surabaya.

Speech Form: 
To all passengers who have left a suitcase or have lost a black suitcase of Polo brand. For baggage laborers or passengers who feel that he may have picked up or seen a polo brand suitcase is requested to be given to information office in fifth deck and then it will be delivered to the owner

Data (2) is a directive speech act of requesting. The lingual marker "requested" is a marker indicating that the utterance is a directive speech act. The speech was delivered by the ship's officer to all passengers. This information usually occurs after a passenger feels that he or she has lost his goods on the ship so he / she asks for help from the ship's officer to look for it, namely by conveying information to all passengers regarding the missing the suitcase. When the ship anchors in the port to take and discharge passengers, the workers in the port can go up and down to offer to help passengers. Based on that reason, the officer delivered the information to the passenger who saw or the baggage worker who took the item or lifted an unknown item in order to request to bring the item to the information office deck 5 so that the lost item could be returned to the owner.

\section{Inviting}

\section{Data 3:}

Context:

This information is conveyed by the ship officer to all passengers approximately 30 minutes before the prayer time arrives.

\section{Speech Form:}

Assalamualaikum warahmatullahi wabarakatu. The prayer time of Zuhur is 11.43 minutes on the ship. The direction of the qibla on the stern of the ship or behind the ship is dragged to the right 35 degrees to all muslem, let us carry out Zuhur prayers in musholla Al-Hikmah located on the 7th deck in the back. Wassalamu alaikum warahmatullahi wabarakatu.

Data (3) is a directive speech act. The phrase "let us" is a lingual marker which shows the directive's utterance as an inviting speech act. The speech was delivered by the ship officer to all Muslim passengers on ship. This information is always conveyed by the ship officer to all passengers on ship when the prayer time comes. Information of prayer times on ship is usually different from the time on land and also Qibla direction to perform prayers that can change. In addition, this prayer time information also aims to invite Islamic passengers to pray together at the musholla on the deck 7 of the ship.

\section{Ordering}

Data 4:

Context:

Information is communicated by ship officers when new passengers from the port enter the ship and they are looking for their places.

Speech Form: 
Passengers who store goods on mattresses or empty beds immediately move them because passengers will occupy according to the seat.

The data (4) is directive speech act. This utterance was conveyed by the ship's officer to the advanced passenger who had occupied the previous place on the ship. The language utterance "immediately move them" in the data is a lingual marker in the ordering of the sub directive speech act. This communication was carried out by officers to passengers especially advanced passengers because they often placed their belongings in the places or seat that were not theirs so that when new passengers who boarded the ship often had difficulty finding their place or when they found their place, the new passengers were mostly do not dare to occupy when there is already an item in that place. Therefore, the speech was shown to order passengers to move their belongings.

\section{Directing}

Data 5:

Context:

This information was conveyed by the ship's officer a few hours before the ship will anchor at Baubau port.

Speech Form:

To all passengers who will descend at the port of Baubau which are on third deck and fourth deck, you do not need to go up on fifth deck. There are stairs to go down on fourth deck.

Data speech (5) is directing of sub-directive speech act. The phrase "stairs to go down are on fourth deck " is a lingual marker of directing speech act. On ship Dorolonda, there are 4 stairs or doors that can be used by passengers who descend or board the ship. The 3 stairs or doors are on fourth deck and one of the stairs that are on fifth deck. To make it easier for passengers doing the process of getting off the ship. The ship officer directs passengers, especially passengers on third and fourth deck to pass through the door on fourth deck and does not need to pass stairs on fifth deck. In addition, the stair on fifth deck can be used by passengers on deck 5 and 6 to get down port.

\section{Requiring}

\section{Data 6:}

Context:

This information is phrased by the ship's officer to a passenger who feels he has lost a ticket on the ship.

Speech Form:

To Paiman, Surabaya-Makassar passenger, your ticket is dropped, you can pick it up in information of fifth deck by carring your identity card. 
The data (6) is requiring speech act. The phrase "by carrying your identity card" is a lingual marker of the directive form of requiring speech act. The ship officer informs passengers who feel they have lost their ticket to pick up their ticket at information of fifth deck. However, before the passenger can pick up the ticket, the passenger must bring identity card (KTP) of passenger in order to ensure that the ticket and identity card are the same.

\section{Expecting}

Data 7:

Context:

This speech is delivered by the ship's officer to all passengers when the ship has anchored at the destination port

Speech Form:

...Congratulations to your destination until we meet with the upcoming voyage.

Data speech (7) is expecting speech act. This speech is phrased by the ship's officer to passengers so that the next cruise, passenger can use this Pelni Ship, Ship Dorolonda, to take their trip again. The utterance "meet with the upcoming voyage" is a lingual marker that indicates the ship officers expect passengers to return to voyage together again later.

\section{Prohibiting}

Data 8:

Context:

This information is communicated to all passengers on the ship, especially to passengers who like to smoke.

Speech form:

To passengers who like to smoke, you are prohibited from smoking in ships' rooms or in halls, on stairs on the ship.

Data speech (8) is a directive speech. Lingual markers "prohibited" to show this utterance is prohibiting speech acts. On sea transportation, passengers are not allowed to smoke in several places on the ship. The ship officer informs passengers who have a hobby of smoking so that they do not smoke in the ships' rooms or in the hall and on the stairs. Prohibition by officers to passengers to avoid the danger of fire. In addition, if smoking indoors, the cigarette smoke of passengers can disturb the other passengers who do not like smoking and will also make the air conditioner to be broken on the ship.

\section{Limiting}

Data 9:

Context: 
This information is delivered by the ship's officer when going to play movies in the ship cinema.

\section{Speech Form:}

In the next 5 minutes, a movie theater or cinema located on the front second deck will present a film entitled I Spit on Your Grave in the first part. This film is presented to those of you who are 17 and above.

Data utterances (9) are speeches which contain directive speech acts of limiting. The saying "this film is presented to those of you who are 17 and above" is a lingual marker that displays a limit age for passengers who want to wacth the film. When the officer informed the film screening, the officer always gave an explanation of the film like what the storyline was, who played a role in the film, and also an explanation of who could watch it. Based on the utterances conveyed by the officer, the film is directed to passengers who are aged 17 and above so that the information from the speech is a limiting speech act.

\section{Allowing}

\section{Data 10:}

Context:

This information was told by officers to a number of passengers while opening the door of the ship to the outside deck after the ticket inspection process was completed.

Speech form:

Please, smoking sir

Data (10) is directive speech acts that is allowing speech. In the phrase, there is a lingual marker "please" which means to allow. The speech was told by the officer to the passengers who were waiting in front of the door of the deck leading to the ship's exit or the ship's outer deck. On the ship, passengers can only smoke on the deck outside the ship or places that are directly related to free air. During ticket inspection, some passengers who want to smoke on the deck outside the ship cannot because the outside deck door is locked. When the ticket inspection process was completed, the officer opened the door while allowing passengers to smoke to the outside deck of the ship.

\section{Advising}

\section{Data 11:}

Context:

The ship officer informs all advanced passengers who want to go down to the land when the ship anchored in the port.

Speech Form:

To Passengers, remember! half an hour before leaving (2x), you are back on the ship. The ship will depart tonight at 9:00 p.m. 
Data speech (11) is an advising speech act with a lingual marker "remember". The speech was shown to remind advanced passengers who want to get down. The ship officer remembers the passenger when the ship was leaving and also gave confirmation by repeating utterances "remember half an hour before leaving" to avoid any advanced passengers left on land because they forgot when the ship was leaving.

\section{Suggesting}

\section{Data 12:}

Context:

This information was conveyed by the ship's officer to passengers who had just boarded the ship and did not know the location of their bed.

Speech Form:

We inform all new passengers who have not understood their beds or seats to ask our officers who are closest or around you.

Data (12) is directive speech acts of suggesting speech. The speech presents the advice given by speakers, namely ship officers to passengers, especially new passengers on board to ask for help from ship officers who are around them if they have difficulty finding a place inside the ship. On each decks and places where passengers always pass, there are officers who are always available to provide assistance to new passengers who have difficulty finding their place on the ship.

\section{Obliging}

\section{Data 13:}

Context:

This information was conveyed by the ship officer to passengers who had just boarded from the port of Tanjung Perak Surabaya about the new rules on the ship.

\section{Speech Form:}

Good evening, it was informed to the passengers who had just boarded the Port of Tanjung Perak Surabaya, at this time in the ship of KM Dorolonda, the passenger had to adjust his ticket with his bed or seat number. To newly boarded passengers, one ticket belongs one passenger and must be in accordance with your ticket.

Data speech (13) is a directive speech act. Speeches delivered by ship officers to new passengers who are on ship with the saying "at this time it has been applied that one ticket belongs one passenger and must be in accordance with your ticket" is obliging speech act. Passengers are obliged to search for and use places on ship according to the ticket number they have. Ticket regulation in accordance with the place is a new rule that must be followed by passengers in order to provide comfort and safety for passengers looking for a place and do not need to scramble with other passengers on ship. 


\section{CONCLUSION}

From the results of the research conducted, it can be concluded that usage of language communication occurring on the ship has significant function to set up secure and confortable circumstance to community as passengers on the ship. Language speech which was applied to produce them is directif speech act. There are 13 sub types of directive speech act, on the ship, including: asking, requesting, inviting, ordering, directing, requiring, expecting, prohibiting, limiting, allowing, suggesting, advising, and obliging.

\section{References}

[1] Sumarlam, S. Pamungkas, and R. Susanti, Pemahaman dan Kajian Pragmatik. Solo: BukuKatta, 2017

[2] S. Levison, Pragmatics. New York. Cambridge Universtiy Press, 2008

[3] Rustono, Pokok-pokok Pragmatik. CV IKIP Semarang Press: Semarang, 1999

[4] Y. Huang, Pragmatics. New York: Oxford University Press.Inc, 2007

[5] E.T. Sulistyo, Pragmatik: Suatu Kajian Awal. Surakarta: UPT UNS Press, 2013

[6] F. Midel, Pengantar Sistem Transportasi. Jakarta: Erlangga, 2012

[7] Sumiatun. "Tindak tutur direktif guru dan siswa dalam pembelajaran di kelas III SDN tipo palu," Bahasantodea., vol 4, no 1, pp 104-112, januari 2016.

[8] M. Safar. "Tindak tutur direktif dalam transaksi jual beli di pasar sentral watampone," Humanus., vol.15, no 4, pp 167-176. Oktober 2016

[9] L. Qomariyah, "Tindak tutur direktif (TTD) guru dalam pembelajaran bahasa arab," Arabi: Journal of Arabic Studies., vol 2, no.1, pp 2-18, 2017

[10] R. Santosa, Metode Penelitian Kualitatif Kebahasaan. Surakarta: UNS Press, 2017

[11] Sudaryanto, Metode dan Aneka Teknik Analisis Bahasa. Yogyakarta: Duta Wacana University Press, 2015

[12] G. Leech, Prinsip-Prinsip Pragmatik. Terjemahan Oka MDD. Jakarta: Penerbit UI Press, 1993

[13] K. Rahardi, Pragmatik Kesantunan Imperatif Bahasa Indonesia. Jakarta: Erlangga, 2005 